\title{
Determining Emotions and the Burden of Proof in Investigative Commissions to Palestine
}

\author{
LORI A. ALLEN \\ Department of Anthropology and Sociology, SOAS, University of London
}

IN T R O DUCTION

In 1919, on the eve of the Paris Peace Conference that would divvy up the postOttoman Middle East among European powers, U.S. President Woodrow Wilson dispatched the King-Crane Commission to Syria (including Palestine). Its stated mission was to assess "the state of opinion there with regard to [the post-Ottoman Middle East], and the social, racial, and economic conditions" that obtained, in order to guide the Peace Conference in assigning mandates. ${ }^{1}$ According to the Commission's announcement about itself, this was "in order that President Wilson and the American people may act with full knowledge of the facts in any policy they may be called upon hereafter to adopt concerning the problems of the Near East-whether in the Peace Conference or in the League of Nations."

As part of that investigation, the Commission spent ten days of their forty-two-day tour in what was then considered "southern Syria," or Palestine.

Acknowledgments: I am grateful to Amahl Bishara, Fabio Gygi, Marloes Janson, Karim Makdisi, David Mosse, Juan Obarrio, Caroline Osella, Paru Raman, Kostas Retsikas, Yezid Sayigh, Ajantha Subramanian, and participants at the Issam Fares Institute for Public Policy and International Affairs-American University of Beirut, the Johns Hopkins Department of Anthropology seminars, and "The Mashriq in the Age of Late Imperialism" workshop at Princeton University. I especially thank the CSSH reviewers for their astute comments on earlier versions of this article, and the journal's editors.

${ }^{1}$ For a summary of the King-Crane Commission, see http://www.oberlin.edu/library/digital/ king-crane/intro.html (accessed 23 May 2015). American Commission to Negotiate Peace, "Future Administration of Certain Portions of the Turkish Empire under the Mandatory System (Secret)," 25 Mar. 1919, Oberlin College Archives, Group 2/6-Henry C. King, King-Crane Commission, Reports and Correspondence, Box \# 128. Cited below as "King-Crane Commission Archives."

2 The King-Crane Commission Report, 28 Aug. 1919: http://www.hri.org/docs/king-crane/syria. html\#statement. Cited below as "King-Crane Commission Report." 
There, the American commissioners heard the same demands made by most of the Arabs they encountered elsewhere in the region (what is today Syria, Lebanon, Israel, and Jordan): residents wanted independence in a multi-faith, united nation of Greater Syria, under the constitutional rule of a monarch, or, if they were forced to be governed by a mandatory state, they wished to be under its temporary tutelage. ${ }^{3}$ The majority did not want a mandate, because, as one commentator said, "Our acceptance of foreign sponsorship would be an admission of our own inability to govern ourselves, and therefore deny us the opportunity at any point in the future to enjoy that right." ${ }^{4}$ But if they were forced to be under a mandate power, the overwhelming preference was for the United States. The majority also opposed the Zionist plan to establish a Jewish homeland in Palestine. ${ }^{5}$ Despite these uniform demands, which one of the commission staff, Albert Lybyer, noted were expressed with "manifest enthusiasm" in "countless earnest appeals," the Great Powers granted the mandate of Palestine to the British, which ruled until Israel gained an independent state in much of the territory in $1948 .^{6}$

Although Lybyer believed the King-Crane Commission was expected to "carry on a really scientific investigation," its records and reports call its "scientific" basis into question. International investigative commissions are explicitly dispatched to find the facts-Who has committed what abuses? What are the causes of the violence? How many people can the land sustain? - that will allow them to reach conclusions and make recommendations to set the conflicting parties - in this case Arab and Zionist, Palestinian and Israeli-on a path to a solution. Yet it is emotion that has consistently been their crucial evidence, and reading affect their method. Affect, the natives" "true" emotions and attitudes, are what the King-Crane Commission investigators were attuned to, and the many commissions that have examined the conflict in Palestine since then have similarly focused on Palestinians' feelings. What investigators have sought, recorded, and interpreted are the nationalist enthusiasms of the Palestinians or, conversely, the superficiality of their patriotism; they have

3 The monarch they chose was Emir Feisal, who had helped establish an Arab government under British protection after they conquered the Ottoman army. Feisal, emissary to the Paris Peace Conference, returned to Damascus in May 1919 to greet the King-Crane Commission.

4 "'Ala abwab al-imtihan" [At the door of the examination], Al-Asima, 25 June 1919, 1.

5 The Commission report noted, "The feeling against the Zionist programme is not confined to Palestine, but shared very generally by the people throughout Syria," with a large majority of the petitions "directed against the Zionist programme." "King-Crane Commission Report," Recommendations Section, I. Syria-Palestine, Point E.

6 Box 16/2 (King-Crane Commission, May-August 1919), Albert H. Lybyer Papers, 1876-1949, Oberlin College Repository, University Archives, University of Illinois at UrbanaChampaign (hereafter, ALP/OCR): http://dcollections.oberlin.edu/cdm/singleitem/collection/kingcrane/id/1840 (accessed 3 July 2013).

7 Harry N. Howard, The King-Crane Commission: An American Inquiry in the Middle East (Beirut: Khayats, 1963), 44. 
measured their levels of sympathy, determined the causes of their anger, probed their pathos, and documented their suffering.

This is despite the fact that, until recently, what Palestinians concentrated on presenting to their examiners were political principles, reasoned arguments, legal proofs, and rational calculations. For each and every commission that has summoned evidence from Palestinians - and there have been tens of themPalestinians have organized their arguments, corralled historical facts, collated statistics, presented photographic proofs, and offered eye-witness testimonies. In these efforts they have tried to present their political demands for liberation in ways that those with final say over their fate might hear and understand their position. Rationality and the language of law have been, after all, the rationale for colonial rule, making it incumbent upon the colonized to adopt these modes as the format for legitimate self-presentation. ${ }^{8}$ But more often than not, their demands have fallen on deaf ears.

This essay explores what happens when facts are called for but emotions are also sought, in the gap between the explicit and implicit rules of the game. It demonstrates how reading affect, as much as reason, is a technology of rule in imperial orders and has served as an unspoken legitimating mechanism of domination. Throughout Palestinians' history of seeking self-determination, their emotion has been identified, or found lacking, in ways that invalidate their political claims and disregard their political subjectivity. Commissions provide a particularly revealing lens onto the ways that affect has worked as a barometer of political worthiness within colonial orders over the last century. The Palestinian case is one of many in a long history of investigative commissions propping up international regimes of inequality. ${ }^{9}$

The power of this investigative method does not reside only in the ways it is used to denigrate the nature of the colonized Other. Its maleficent potency resides in the persuasiveness of more explicit claims to rule by reason, which has led the colonized to think that rational debate and logical argument held sway. The history of international Western commissions to Palestine shows these investigations to have been a mechanism through which colonial agents and "the international community" have given the colonized false hope that discourse and sensible argument were the appropriate and effective methods of politics, when what was required was an impossible balance between the rational and the emotional.

\footnotetext{
8 John L. Comaroff, "Reflections on the Colonial State, in South Africa and Elsewhere: Factions, Fragments, Facts and Fictions," Social Identities 4, 3 (1998): 321-61.

9 See, for example, Adam Ashforth, The Politics of Official Discourse in Twentieth-Century South Africa (Oxford: Clarendon Press, 1990); Radhika V. Mongia, "Impartial Regimes of Truth," Cultural Studies 18, 5 (2004): 749-68; Ann Laura Stoler, Along the Archival Grain: Epistemic Anxieties and Colonial Common Sense (Princeton: Princeton University Press, 2009).
} 
Whereas much of the literature on colonial rule focuses on the role of emotion in delegitimizing claims to self-determination, ${ }^{10}$ I argue that the criteria for judging fitness for self-rule included a much more complex mix of that which was considered reasonable and that which was deemed to be emotion. The demand for the correct emotional performance has always been part of the adjudication. An examination of investigators' claims to be able to access, interpret, and judge the non-discursive dimensions of the subjectivity and stances of the colonized - that is, their affective dispositions-reveals the slippery ways in which imperial powers have employed "reading affect" as a diagnostic tool to produce "facts."

Despite their recognition that the criteria of political legitimacy are always shifting beneath them, Palestinians have persisted in engaging with commissions. There are many reasons for this, foremost among which is their perceived lack of alternatives. ${ }^{11}$ They cooperate with every investigation that presents a means to produce the evidence that might convince "the world" to end the occupation, and more recently to just ease the siege on Gaza. Israel, by contrast, rarely cooperates with UN commissions because the continuity of its settlercolonial project does not rely on doing so and cooperation with commissions would be interpreted as legitimizing their conclusions, which the Government of Israel often disagrees with. ${ }^{12}$ There are many political reasons that investigative commissions continue to be deployed, such as the need of governments and the UN to show that they are paying attention to the conflict. However, to understand what else motivates commissions, and to go beyond observations

10 James W. Fernandez, "Anthropological Inquiry into the Force of the Emotions in the Family of Man: An Overview," Endoxa 33 (2014): 13-36; Edward Said, Orientalism (New York: Vintage Books, 1979).

11 For example, the Palestinians only decided to focus on the Mitchell Committee after it became clear that the peace talks that Clinton convened in Taba, Egypt in 2001 were leading nowhere. Although the negotiators at Taba believed they were close to reaching a deal on final status issues, Israel suspended the talks due to domestic political considerations. "Final Statement at Taba, 28 January 2001." https://www.nad.ps/en/media-room/statements/final-statementtaba; "Shattered Dreams of Peace," Frontline, www.pbs.org/wgbh/pages/frontline/shows/oslo/ negotiations/ (all accessed 26 Dec. 2016).

12 Israel has never cooperated with the Special Committee to Investigate Israeli Practices Affecting the Human Rights of the Palestinian People and Other Arabs of the Occupied Territories, the 2002 UN Security Council-mandated investigation into Israeli attacks on Jenin refugee camp, or with the 2009 Goldstone Commission, or the UN investigation into the attacks on Gaza in 2014. Israel severed ties with the UN Human Rights Council in 2012 after it probed illegal West Bank settlements, and refused to appear before it in the Universal Periodic Review in 2013. Since 2007, Israel has refused to allow access to Israel and the occupied Palestinian territory by all Special Rapporteurs on the situation of human rights in the Palestinian territories; http://www. euromedrights.org/publication/eu-must-end-its-silence-on-justice-and-accountability-for-gaza/ (accessed 26 Dec. 2016). In 2016, a UN Special Rapporteur quit in protest when Israel refused him access to Palestine; http:/guardian.ng/news/un-special-rapporteur-quits-says-israel-denied-him-access-topalestinian-territories/ (accessed 29 Dec. 2016). Israel also regularly refuses to carry out its own investigations of Israel Defense Force soldiers killing civilians. Human Rights Watch, "Promoting Impunity," 2005: http://www.hrw.org/reports/2005/iopt0605/5.htm (accessed 23 May 2015). 
about their obvious effects, we must consider their mechanisms and what they mean to the people involved, situating them within the history of colonialism. ${ }^{13}$

I will show how sentiments have been present as much more than a "halo" for the experts' work, focusing on three investigative commissions: ${ }^{14}$ the 1919 King-Crane Commission, the Anglo-American Committee of Enquiry that investigated the situation of Jews and Palestinians at the end of World War II, and the Mitchell Commission that involved the United States, European Union, Norway, and Turkey in examining the causes of the second intifada in $2001 .{ }^{15} \mathrm{~A}$ striking feature of all three is the emphasis they placed on forensic readings of Palestinian emotions; it was taken for granted that commissioners could read the Arabs' feelings, and it was assumed that this was relevant to their task. Across the period under study there have been significant changes in political context and in the governing institutions that have dominated the commissions, and the kinds of people called on to represent the Palestinians have shifted from notables to NGOs. There have also been changes regarding the value assigned to different emotional states and exactly which feelings are deemed important. And yet analysis of these commissions makes clear that reading affect has remained a fundamental part of political epistemology, not only in the early stages of colonialism and the late colonial period, but well beyond. ${ }^{16}$ These commissions did not change political actions or attitudes among leaders like U.S. President Truman or others, and Palestinians' performances of affect and their well-communicated worthiness may have had little political effect on the Westerners judging them. But investigators' claims to be able to read Palestinians' "true" emotions and intentions were a basis on which commissioners justified their recommendations, and politicians their refusals of Palestinian rights and political entitlements.

INVESTIGATIVE COMMISSIONS: PUTTING POLITICAL EPISTEMOLOGIES TO WORK

There have been numerous investigative commissions to Palestine in addition to the three I analyze here, including British investigations under the mandate,

${ }^{13}$ Key works on Israeli settlers, in colonial history and the present, include: Maxine Rodinson, Israel: A Colonial-Settler State? (New York: Pathfinder, 1973); Edward Said, The Question of Palestine (New York: Vintage, 1992); Gershon Shafir, Land, Labor and the Origins of the IsraeliPalestinian Conflict (Cambridge: Cambridge University Press, 1989); Patrick Wolfe, "Settler Colonialism and the Elimination of the Native," Journal of Genocide Research 8, 4 (2006): 287-409.

14 Dominic Boyer, "Thinking through the Anthropology of Experts," Anthropology in Action 15, 2 (2008): $38-46,45$.

${ }_{15}$ Sources for my analysis include archival research and ethnographic interviews with those involved in investigative commissions, as well as secondary sources on each historical period. Through the use of memoirs, personal papers, and interviews, I have sought perspectives of individual Palestinians involved with each commission and of the commissioners and governments that dispatched them, along with the broader public's reactions to the commissions and their reports.

${ }^{16}$ Christopher Bayly, Empire and Information: Intelligence Gathering and Social Communication in India, 1780-1870 (Cambridge: Cambridge University Press, 1996); Ann Laura Stoler, “Colonial Archives and the Arts of Governance," Archival Science 2, 1-2 (2002): 82-109, 102. 
such as the Shaw and Peel commissions that reported on Zionist-Arab disturbances in the 1920s and 1930s. The UN has also spearheaded many factfinding missions, including the 2009 Goldstone Commission and the Independent Commission of Inquiry on the 2014 Gaza Conflict. ${ }^{17}$ Each commission has consisted of a group of experts of one kind or another, including academics, lawyers, and military men. As with most commissions in the world, each was charged by a government, coalition of governments, or supranational body with investigating a specific set of circumstances. ${ }^{18}$ In Palestine they have usually been prompted by a period of intensified violence.

These investigations are useful to the analyst looking to uncover the logics of political orders. Such investigations often come on the heels of moments of rupture in an ideological formation caused by violent crisis. They invite argument, conducted through multiple media, about the nature and bases of political relations, and they bring international conflicts, as well as government action (or inaction) and policy deliberation, into wider public view. Commissions attract an audience, albeit a temporary one, and bring a public into being around the various texts that a commission produces, including testimonies, videos, speeches, and the commission reports themselves. ${ }^{19}$ They both produce and reflect "political epistemologies," the social processes and categories through which proof and evidence are produced and mobilized in political claim-making. ${ }^{20}$ As such, commissions also provide a special view onto the

17 Other British Royal commissions include: the Palin Commission (1920) that investigated the 1920 riots during the Nebi Musa festival; the Haycraft Commission (1921) that investigated the causes of the 1921 disturbances; the Shaw Commission, a British Parliamentary commission investigating the Western (Wailing) Wall riots in 1929; and the Woodhead Commission (1938), established in response to opposition voices (especially Churchill's) demanding reexamination of partition proposals. The League of Nations Permanent Mandates Commission was established in 1921 and constituted a forum in which Jews and Arabs sought to make political claims, often in terms of international law. See Natasha Wheatley, "Mandatory Interpretation: Legal Hermeneutics and the Arab and Jewish Petitions to the League of Nations," Past and Present 227 (2015): 205-48. The United Nations has sponsored many forms of investigations, including "independent fact finding missions," panels of inquiry, and Special Rapporteurs. A recent UN inquiry commission on Palestine investigated the "Gaza Conflict" and released its report on 22 June 2015: UNHRC, 24 June 2015, UN Doc A/HRC/29/CRP.4; http://www.ohchr.org/EN/HRBodies/HRC/CoIGazaConflict/Pages/ReportCoIGaza.aspx (accessed 26 Dec. 2016). Other investigations include the 2010 Palmer Committee, and independent initiatives including the 1982 MacBride Commission, and the "Public Truth Commission" organized by the Israeli NGO Zochrot.

${ }^{18}$ Truth and Reconciliation Commissions (TRCs) are a distinct form of commission. They emphasize political reconciliation, usually within a nation-state and at the perceived endpoint of a conflict. Because the contexts, purposes, and results of TRCs are so divergent, I do not explicitly compare them with my three Palestinian cases here, but critical analyses of TRCs do inform my approach. See the special issue edited by Greg Grandin and Thomas Miller Klubock, "Truth and Reconciliation Commissions: State Terror, History and Memory," Radical History Review 97 (2007); and Richard A. Wilson, The Politics of Truth and Reconciliation in South Africa (Cambridge: Cambridge University Press, 2001).

19 Michael Warner, "Publics and Counterpublics," Public Culture 14, 1 (2002): 49-90, 50.

20 Bruno Latour uses the concept of "political epistemology" to draw attention to the unstable boundary between politics and science; see his "Review Essay: The Netz-Works of Greek 
changing justifications for colonial and other forms of managing conflict, and onto the assumptions underlying how adequate political justifications are determined and asserted. Each investigation of the Israeli-Palestinian conflict has been shaped by and reflects systems of political thought and political trends according to which Palestinian worthiness of self-rule has been argued and evaluated.

The manner in which scholars and others discuss and analyze commissions is itself part of the process of producing and maintaining confusion about what they do, and obscures the functioning of political epistemologies. Most commentary reproduces the claim that government policies and plans are based on logic and facts, a notion upon which commissions are premised. ${ }^{21}$ Throughout the centuries of world history in which investigative commissions have been a tool of governance - some say the Domesday Book of 1086 was the first ${ }^{22}$ - those involved have usually asserted their thoroughness, accuracy, and objectivity and the balanced, unbiased nature of their investigators. ${ }^{23}$ Governments (and occasionally universities and professional associations) have set up commissions to investigate a variety of phenomena, including violent events, policies, war crimes, famine, histories of national conflict, and race relations. Even with this variety, scholarship and public discourse about investigative commissions consistently assess them on similar grounds - of accuracy, objectivity, and results - that accord with the self-understanding of commissions themselves. There is no consensus on how to evaluate commissions or measure their impact, since they have vastly differing forms, effects, and

Deductions," Social Studies of Science 38 (2008): 441-59; Duncan Kennedy, "Knowledge and the Political: Bruno Latour's Political Epistemology," Cultural Critique 74, 1 (2010): 83-97. I use the notion somewhat differently, in that I accept that some frameworks for interaction (such as investigative commissions and government lobbying) are explicitly political and popularly recognized as such, and then seek to understand what counts as knowledge and fact within a political context. For a parallel kind of approach to epistemology, see Andreas Glaeser, "Power/Knowledge Failure: Epistemic Practices and Ideologies in the Secret Police of Former East Germany," Social Analysis 47, 1 (2003): 10-26.

21 A similar point is made in Beng-Huat Chua, "Democracy as Textual Accomplishment," Sociological Quarterly 20, 4 (1979): 541-49, 543. For examples, see Hugh Davis Graham, "The Ambiguous Legacy of American Presidential Commissions," Public Historian 7, 2 (1985): 525, 8, 18; and Hugh Davis Graham, "On Riots and Riot Commissions: Civil Disorders in the 1960's," Public Historian 2, 4 (1980): 7-27, 14.

22 Ivor Richardson, "F W Guest Memorial Lecture 1989 Commissions of Inquiry," Otago Law Review 7, 1: 1-13: http://papers.ssrn.com/sol3/papers.cfm?abstract_id=2189704 (accessed 23 May 2015); Information on the Domesday Book is available at: http://www.domesdaybook.co.uk/index. html (accessed 23 May 2015).

23 For example, see Jonathan Beck, "Head of UN Gaza Commission Rejects Claims of Bias," Times of Israel, 22 June 2015: http:/www.timesofisrael.com/head-of-un-gaza-commissionrejects-claims-of-bias/ (accessed 29 June 2015); and "The Bahrain Independent Commission of Inquiry Statement," which asserts that it is "independent and free from any interference": http:// www.bahrainrights.org/en/node/4499 (accessed 23 May 2015). 
scholarly interpretations. ${ }^{24}$ They have been seen as "a first step in law creation," an abdication of governmental responsibility, a "pacifying mechanism" and a method to block reform, or a catalytic inciting controversy. ${ }^{25}$ More critical analyses have tried to determine the bias of investigators or the political effects of commission reports, or to unravel the political chicanery and machinations that infiltrate commission work. ${ }^{26}$ In many cases these assessments are made from the perspective of on-going political contests. ${ }^{27}$

Another thing consistently remarked on across all national cases is the political nature of commissions, with UN commissions coming under particularly sharp critique for an apparent bias that skews their results. ${ }^{28}$ The regular use of commissions to exonerate government policies and actions is apparent in diverse historical cases and locations. The 9/11 Commission Report, for example, provided "an official narrative of the events that gave rise to the "war on terror"' that helped justify that war in the United States. The Royal Commission Report of 1834 supported the rescinding of welfare for the poor in England. ${ }^{29}$ The Iran-contra Hearings, a different kind of spectacle, constituted "a civic ritual" in which public representatives could "pass judgment on the legal and moral status of actions taken in the highest office in the land," but in the end it fed into "collective forgetting" of the scandal and Oliver North emerged relatively unscathed. ${ }^{30}$

\footnotetext{
24 Mike Rowe and Laura McAllister, "The Roles of Commissions of Inquiry in the Policy Process," Public Policy and Administration 21, 4 (2006): 99-115.

25 Barbara Lauriat, "The Examination of Everything': Royal Commissions in British Legal History," Statute Law Review 31, 1 (2010): 24-46, 24.

26 For example, see Rob Grace, "Impartiality and the Bahrain Commission," ATHA (2011): http://www.atha.se/content/impartiality-and-bahrain-commission (accessed 26 May 2015); Arthur Lenk, "Fact-Finding as a Peace Negotiation Tool—-The Mitchell Report and the Israeli-Palestinian Peace Process," Loyola of Los Angeles International \& Comparative Law Review 24, 289 (2002): 289-325: http://digitalcommons.lmu.edu/ilr/vol24/iss3/1; M. Cherif Bassiouni, "From Versailles to Rwanda in Seventy-Five Years: The Need to Establish a Permanent International Criminal Court," Harvard Human Rights Journal 10, 11 (1997).

27 See, for example, S. E. Knee, "The King-Crane Commission of 1919: The Articulation of Political Anti-Zionism," American Jewish Archives 29, 1 (1977): 22-53. Patrick traces the afterlife of the Commission. Andrew Patrick, "Reading the King-Crane Commission of 1919: Discourses of Race, Modernity, and Self-Determination in Competing American Visions for the Post-Ottoman Middle East" (PhD diss., University of Manchester, 2011).

28 See for example Asher Maoz, "Historical Adjudication: Courts of Law, Commissions of Inquiry, and 'Historical Truth,"' Law and History Review 18, 3 (2000): 559-606; Nissim BarYaacov, The Handling of International Disputes by Means of Inquiry (London: Oxford University Press, 1974).

29 Darryl Li, "Lies, Damned Lies and Plagiarizing 'Experts,"” Middle East Research and Information Project 41 (2011): http://www.merip.org/mer/mer260/lies-damn-lies-plagiarizing-experts (accessed 3 Apr. 2016); Fred Block and Margaret Somers, "In the Shadow of Speenhamland: Social Policy and the Old Poor Law," Politics \& Society 31, 2 (2003): 283-323.

30 Michael Lynch and David Bogen, The Spectacle of History: Speech, Text and Memory at the Iran-Contra Hearings (Durham: Duke University Press, 1996), 89, 238.
} 
Another typical observation about commissions is that their recommendations are usually "laboriously arrived at and then customarily ignored."31 Even while criticizing them for producing no useful results, however, this sort of critique remains within the logic and reasoning of the inquiry commissions' terms of reference. It starts from an assumption that all the hard work, time, and expense that governments invest in their inquiries should not be ignored. Such arguments presume that investigative commissions seek facts, and that the processes involved in finding the facts bear a significant relationship to the commission's results, or should do so. They accept that the commission of inquiry's goal is to come to conclusions from those facts and make recommendations that will lead to improvement in some political situation. From this premise, the quality of the investigative processes, the credibility of the facts and fact-finding personnel, and the nature of the deductions and resultant recommendations are then judged, and often found lacking.

Although it is uncommon for studies to consider commissions beyond their own terms of reference and policy effects, a few have analyzed commissions from a more Foucauldian perspective as fora in which forms and producers of knowledge are legitimated or discredited. ${ }^{32}$ They have examined commissions for what they reveal about "ruling orders," to understand how the states that dispatch them conceive of "questions of sovereignty, citizenship, and territorial division," and to determine how commissions "create the categories they purport only to describe," and thereby support structures of domination and political exclusion. ${ }^{33}$ These studies are interested in commissions as a tool of ruling orders, but they tend to approach the problem through trying to understand the rulers; they base their analyses on readings of commission reports with an eye trained on the rhetorical strategies and the discursive constructions of social categories by the dominant. ${ }^{34}$

My analysis starts instead by asking how the ruled try to speak to the rulers. By exploring the micro-interactions of investigator and investigated through archival research, testimony, memoirs, and personal papers, and through ethnographic interviews with people involved in these commissions,

31 Chua, "Democracy as Textual Accomplishment," 543; Graham, "On Riots and Riot Commissions," 21; Muhammad Fādil al-Jamālī, Memoirs and Lessons (Beirut: Dar al-katib al-jadid, 1964), 78 (in Arabic).

32 Ashforth, Politics of Official Discourse; Michael Gilsenan, Lords of the Lebanese Marches: Violence and Narrative in an Arab Society (London: I. B. Tauris Publishers, 1996), 69-78; Mongia, "Impartial Regimes of Truth"; Stoler, Along the Archival Grain.

33 Ashforth, Politics of Official Discourse, 4; Stoler, Along the Archival Grain, 27; Jane Cowan, "Who's Afraid of Violent Language? Honour, Sovereignty and Claims-Making in the League of Nations," Anthropological Theory 33, 3 (2003): 271-91; "The Supervised State," Identities: Global Studies in Culture and Power 14, 5 (2007): 545-78; "Fixing National Subjects in the 1920s Southern Balkans: Also an International Practice," American Ethnologist 35, 2 (2008): 338-56.

34 Especially Ashforth, Politics of Official Discourse. 
we can start to grasp the workings of political hegemony from the perspective of the dominated, and the interplay between political epistemologies of ruling orders and the right-claims of subjects. ${ }^{35}$ This approach helps us understand the mechanisms through which the ruled are led to misunderstand the nature of the regime that is maintaining their subordination. Commissions hold up the promise of reasonableness in policy-making. They are framed in a way that leads interested observers to believe that the perceptions and concerns of the groups under scrutiny will be rationally considered. Using the language of evidence, proof, and objectivity, and drawing on the tools of law and sometimes positivist social science, they invite interested parties into public discussion to prove themselves reasonable political subjects. The irony is that it is the commissioners' presumed emotional perspicacity - their claim to be able to read the affect of the investigated - and not their reasonable considerations, that has helped justify their rejection of Palestinians' political demands.

THE KING-CRANE COMMISSION, 1919

In U.S. President Woodrow Wilson's "Fourteen Points" speech before Congress in 1918, he advocated the equality of nations, consent of the governed, and self-determination as principles for political arrangements after World War I. ${ }^{36}$ The hope that his proclamations gave to the colonized was an important part of the context of the King-Crane Commission, and helped shape the terms of the debate with the Arabs while the League of Nations was in formation. ${ }^{37}$ Arab spokespeople drew on Wilson's language of justice as a validating pillar for their own political demands. ${ }^{38}$ One of the Palestinian delegations to the King-Crane Commission asked that the Peace Conference meeting in Paris at the time "defend the right of general humanity" 39 in line with

35 In her study on the role of sympathy in imperial state-building, Danilyn Rutherford has noted the dearth of focus on "the real-time interactions between officials and their subjects that make up colonial practice," but her emphasis is still on the political work of feeling among colonial rulers rather than the ruled: "Sympathy, State Building, and the Experience of Empire," Cultural Anthropology 24, 1 (2009): 1-32, 4.

36 Erez Manela, The Wilsonian Moment: Self-Determination and the International Origins of Anticolonial Nationalism (Oxford: Oxford University Press, 2007), 23.

37 Ussama Makdisi, Faith Misplaced: The Broken Promise of U.S.-Arab Relations: 1820-2001 (New York: Public Affairs/Perseus Books, 2010), 125. The King-Crane Commission Report also notes, "President Wilson's Fourteen Points, had made a deep impression upon the Syrian people and lay in the background of all their demands."

38 Akram Zu'aytir, "Protest to Wilson, 15 March 1919 from Palestinian Colony of San Salvador," Watha'iq al-haraka al-wataniyya al-filastiniyya 1918-1939: Min awraq Akram Zu'aytir (Beirut: Institute for Palestine Studies, 1984), 10. Western politicians also recognized the importance of invoking Wilson: "Many Allied officials felt, as Walter Lippmann noted, that before beginning a foreign policy statement they had to take a kind of immunity oath by prefacing their remarks with a pledge to Wilson's ideas." Joseph L. Grabill, Protestant Diplomacy and the Near East: Missionary Influence on American Policy, 1810-1927 (Minneapolis: University of Minnesota Press, 1971), 121.

39 "The Committee to Haifa, Akka, and the End of the Journey," Watha'iq al-haraka, 2. 
Wilson's liberal principles. Prince Feisal, who was one of the Arabs' emissaries to the Peace Conference and main Arab leader in Greater Syria, said that he could be "confident that the [Great] Powers will attach more importance to the bodies and souls of the Arabic-speaking peoples than to their own material interests." 40

Although there were expressions of cynicism about what the King-Crane Commission was really up to, many among those writing about the Commission's activities at the time seemed to accept its goals in good faith. ${ }^{41}$ In a protest letter to British General Allenby in 1918, the Muslim-Christian Association, a Palestinian civic club, asked rhetorically, "So can the destiny of Palestine be determined before taking the opinion of people?" "We don't think so," was its buoyant response. ${ }^{42}$ The King-Crane commissioners had publicly assured the Arabs that "the Allied powers did not undertake war to expand the extent of their possessions, but to protect justice and that which was right, over power and oppression." 43 The principles of peace and justice between nations, which Woodrow Wilson was championing, encouraged the belief among Palestinian nationalists that they could prove, through reasoned argument and proper political performance, that their nationalism deserved a state. The King-Crane Commission elicited answers to the explicit question, "What kind of government do you want?" Their Arab respondents also answered an implied question, "What kind of nation do you claim to be?"

So how did the King-Crane Commission attempt to gather the opinions of the Arab people? ${ }^{44}$ The Commission was to consist "of men with no previous contact with Syria." This would, Wilson believed "convince the world that the [Peace] Conference had tried to do all it could to find the most scientific basis possible for a settlement." 45 Regardless of how organized and "scientific" the Commission actually was, the language and form of objectivity, science, and fair representation appears repeatedly throughout its final report. They were

\footnotetext{
${ }^{40}$ George Antonius, The Arab Awakening: The Story of the Arab Awakening (New York: Capricorn Books, 1965 [1946]), 287.

41 Hilu Bulus, "Al-mas'ala al-suriyya," al-Muqattam, 9 July 1919, 2; 'Aisa Suqary, "Al-lejna al-dowliyya fi filastin," Al-Muqattam, 20 June 1919; “Al-lejna al-dowliyya fi yafa," (authors unknown) Al-Muqattam, 23 June 1919; Makdisi, Faith Misplaced, 144 n66.

42 Zu'aytir, Watha'iq al-haraka, 2. They were perhaps unaware of how little Wilson and his deputies were concerned with territories outside Europe. Manela, Wilsonian Moment, 24, 40-41. Wilson had already privately approved a draft of Balfour's pro-Zionist statement. Benny Morris, Righteous Victims: A History of the Zionist-Arab Conflict, 1881-2001 (New York: Vintage Books, 2001), 75.

43 "Interviews of the King-Crane Commission in the Corners of Palestine and East Jordan, June 1919," Zu'aytir, Watha 'iq al-haraka, 29.

44 Wilson advocated the creation of a new league of nations to facilitate a global moral commitment to peace through rational discourse to mobilize public opinion. Lloyd E. Ambrosius, "Woodrow Wilson, Alliances, and the League of Nations," Journal of the Gilded Age and Progressive Era 5, 2 (2006): 139-65.

${ }^{45}$ Patrick, "Reading the King-Crane," 27; "Interviews," Watha'iq al-haraka, 23-24.
} 
clearly anxious to present themselves as impartial observers and to produce a report that appeared objective. In one instance, their actions were literally a performance, complete with costume. An Arabic language newspaper reporting on the investigators' visit "noticed that some of the members wore on their arms a piece of cloth with the [Arabic] word meezan" [scales, balance] on it, indicating that "justice" was a guiding principle of their work. ${ }^{46}$

The mass of documents the commissioners assembled shows evidence of their investment in the aesthetics of authoritative knowledge. ${ }^{47}$ What counted as data was that which could be counted: expressions of opinion by representatives from a representative number of groups. They used the scientific forms of statistics and tables to constitute social groups, and they determined how many petitions and delegations were needed to be representative through simple assertion. Maps of religious and "racial distributions" were also integral to the report. ${ }^{48}$

They also affirmed the representative nature of their findings by showing how many different kinds of groups they met with. These were categorized according to political type, economic group, and religious affiliation. Muslims were subdivided into Sunni, Shi' ite, and, interestingly, "Moslem Ladies." 49

It was not only the Commissioners who were concerned to represent their work as being objective and truly representative, of course. The Arab leadership who helped organize the Commission's visit also strove to present it in a way that would enhance the credibility of their own position. Here we come to the double bind in which the Arab representatives found themselves: how could they leverage popular sentiment and prove that their position was representative of the population as a whole, and demonstrate publicly that this was a national population deserving of an independent nation, but at the same time prevent their people from coming across as disorderly crowds? ${ }^{50}$

46 Ibid.

47 Saida Hodzic, "Ascertaining Deadly Harms: Aesthetics and Politics of Global Evidence," Cultural Anthropology 28, 1 (2013): 86-109, 90; Marilyn Strathern, Partial Connections (Walnut Creek: AltaMira, 1991), 10.

${ }^{48}$ In addition, the commissioners carried with them a reading list that included ethnographic history books, some written by Christian missionaries to the Near East, as well as "statistical and economic data," maps of physical features of the land and political boundaries, and information on the political situation "showing as accurately as possible" present claims of groups. "King-Crane Commission (May-August 1919)," box 16/1 ALP/OCR: http://dcollections.oberlin.edu/cdm/singleitem/collection/kingcrane/id/1840 (accessed 3 July 2013).

${ }_{49}$ They conceded that in Palestine they saw proportionally far more Christian groups. Of the nine members of the Commission, seven had ties to Christian missionary activity in the Near East, and three were preachers themselves. Grabill, Protestant Diplomacy, 199.

${ }^{50}$ The fear of the Arab mob, and colonial tendencies to blame the Arab mob as collective perpetrator, extend throughout history. See Gregory Starrett, "Authentication and Affect: Why the Turks Don't Like Enchanted Counterpublics, A Review Essay," Comparative Studies in Society and History 50, 4 (2008): 1036-46. In its investigation of the disturbances across Palestine in 1921, the Haycraft Commission pointed to an Arab mob that was "too excited to listen to 
In one response to this challenge, political groups and the central Arab Government organized a large petition campaign. The Commission tallied over ninety thousand signatures on the 1,863 petitions. Emir Feisal also spoke the language of impressive numbers, declaring to the Commission that he was "authorized to represent [the people] by official documents containing over three hundred thousand signatures." $" 51$

In addition to the petitions, demonstrations were staged throughout Syria and Palestine. As James Gelvin has noted, Arabic news articles from the time reflect a population concerned to prove themselves "civilized," "mature," and "intelligent" in front of the commissioners so as to show that they deserved an independent state. They held "orderly demonstrations showing their national sentiments and desires." ${ }^{, 52}$ With these quick, quiet demonstrations, we come to the problem of emotions.

The task for the Arab government trying to prove to the democratic Western powers their fitness for self-rule was to display a certain kind of public that could exhibit the appropriate sensibility: unified and "on message" with a single slogan; a public that was actually in public. With this as a backdrop to their message, they could declare that the population was not only on board with the independence plan, but also in public without being an unruly mob.

And so it was. An observer describing the demonstrations in a local newspaper wrote that it was perfect: "quiet, without tumult, no speeches-yet through its silence the demonstration announced the advancement of the people." ${ }^{53}$ These quiet demonstrations were a physical embodiment of the orderly modernity of the Arab nation, and their status, therefore, as deserving an independent state. ${ }^{54}$ They believed that presenting their unity in a disciplined form was required to convince the Commission. "It is imperative that we unite our voices in the call for complete autonomy," a commentator urged in a local newspaper. In this article, entitled "At the Doors of the Examination," he wrote that their voices, united in a demand for autonomy, would "push the commission and [peace] conference to view our self-sufficiency and suitability for rule, as the nation that succumbs to slavery and humiliation

reason." "Palestine. Disturbances in May, 21. Reports of the Commissions of Inquiry": https:// archive.org/stream/palestinedisturb00grearich/palestinedisturb00grearich_djvu.txt. (accessed 29 Dec. 2016). In more recent times, groups of protesting Arabs have been referred to as "the Arab street." See Asef Bayat, "The 'Street' and the Politics of Dissent in the Arab World," Middle East Report 226 (2003): 10-17.

${ }^{51}$ Howard, King-Crane Commission, 121.

52 In James Gelvin, Divided Loyalties: Nationalism and Mass Politics in Syria at the Close of Empire (Berkeley: University of California Press, 1998), 263.

${ }^{3}$ Ibid., 264.

${ }^{54}$ Ibid., 20. 
will never earn respect." 55 Presentation of a unified voice was itself assumed to be an index of political worthiness.

The well-publicized Article 22 of the League of Nations also formed part of the discursive framework shaping the terms of the debate. ${ }^{56}$ The League insisted that a mandate was necessary to train the Arabs into independence, and Article 22 spelled out the League's new form of colonial power in the shape of Mandatory "tutelage." 57 Many Arab commentators refused Article $22^{58}$ as well as the categorization of them as, "peoples not yet able to stand by themselves under the strenuous conditions of the modern world," as the League defined them. ${ }^{59}$ Although the Arabs were designated "peoples not yet able to stand by themselves," they (including Syria and Lebanon, Palestine and Transjordan, and Iraq) were at the top of the list among the "A" Mandates: peoples who were "provisionally recognised as independent," but would receive "the advice and assistance of a Mandatory in its administration until such time as it is able to stand alone."60 The Palestinians asserted that their people were already standing. They were being educated in America and Europe, delegations told the Commission, and so they had among them all the professions necessary for producing a functioning country, from farmers to pharmacists, mechanics to mathematicians, making them "ready with all the necessary tools for independence.",61

But there was no convincing some. William Yale, one of the commission advisers, doubted the possibility of developing a Syrian national spirit. He insisted that "this liberal movement [currently] was too feeble ... to rally to their support the ignorant, fanatical masses which are swayed by the Ulemas [religious scholars] and the Young Arab Party" (an Arab nationalist group). ${ }^{62}$

\footnotetext{
55 "Ala abwab al-imtihan," Al-Asima, 25 June 1919, 1.

56 "An Analysis of the Syrian-Palestine Situation in 1919: The American Point of View," 1928, box7/1, William Yale Papers, Boston University (hereafter, WYP/BU).

57 The League of Nations Charter is available at: http://avalon.law.yale.edu/20th_century/ leagcov.asp\#art22 (accessed 28 Dec. 2016).

58 Article 22 had been well publicized and shaped Palestinian claims to the League of Nations.
} William Yale, "Thesis submitted in part requirement of Master's degree by William Yale. 1928. Title: An Analysis of the Syrian-Palestine Situation in 1919 The American Point of View," box 7/1/6, WYP/BU. Natasha Wheatley, “The Mandate System as a Style of Reasoning: International Jurisdiction and the Parceling of Imperial Sovereignty in Petitions from Palestine," in Cyrus Schayegh and Andrew Arsan, eds., The Routledge Handbook of the History of the Middle East Mandates (New York: Routledge, 2015), 109.

59 Khalil al-Sakakini, Yawmiyyat Khalil al-Sakakini, Volume 3: Ikhtibar Al-Intidab w As'ilat Al-Hawiyya 1919-1922, Akram Musallam, ed. (Ramallah: Khalil Sakakini Cultural Centre, and Jerusalem: Institute of Jerusalem Studies, 2004), 175.

60 "The Principles of the Mandatory Regime": http://unispal.un.org/UNISPAL.NSF/0/ C61B138F4DBB08A0052565D00058EE1B (accessed 29 May 2015).

61 Zu'aytir, Watha'iq al-haraka, 29.

62 Cited in James Gelvin, "The Ironic Legacy of the King-Crane Commission," in David W. Lesch, ed., The Middle East and the United States: A Historical and Political Reassessment, 2d ed. (Oxford: Westview Press, 2012), 20 n23. 
This was despite many assurances by Feisal, the Arab leader, that what the Arabs wanted was a non-sectarian nation-state, and despite the Arab delegations' repeated pledges to the Commissioners that minority rights - in this case Christian and Jewish — would be protected. The long presence of Arabs in Palestine and their demographic majority was, for Arab commentators, argument enough against the Jewish claim to Palestine as a national home. Jewish demands for rights to the land "based on colonization of the area from a different century" was, in their view, unreasonable given that "by that logic this would mean that Arabs could claim Spain, or the Romans or Greeks [could] claim anywhere they were," as some wrote in a letter of protest. ${ }^{63}$ Judaism was a religion, not a nation. ${ }^{64}$ The Christian-Muslim Association wrote in a letter to the Military Ruler in 1918 that they had no "doubt that the civilized world [would] not permit that which is not reasonable." 65

But William Yale, the technical adviser on Southern Syria, was skeptical that there was "any genuine sentiment of nationalism in Syria," and he felt "a distinct note of pan-Arabism and Pan-Islamism." Religious sentiment, if it was Muslim religious sentiment, could not be a valid basis for national unity. He deemed those Arabs who rejected the League's Article 22 to be a "fanatical element" fueled by their "profound anti-western feeling."66 Yale said that it was by "a clever, well organized and thorough propaganda the Moslems of Palestine and Syria have been united on a program which superficially has every sign of being Syrian nationalism, but which is basically Islamic." 67

It is not just that Arab emotion was an important element of the equation that had to be performed for their assessors, but it had to be performed correctly, to be calibrated as properly national and not improperly supra-national or Islamic fanatical, or, as we will see, boring. To Yale, that the petitions were so uniform, so clear in their requests for independence indicated that the masses supported nationalism with no understanding of it. Not only did the perceived lack of nationalist emotion disqualify the Palestinians, so too did the emotional pull of pan-Arabism and pan-Islamism. Emotion was expected to be spontaneous, but not if it spilled over territorial boundaries, pulling the

63 The note on this "protest from Muslims and Christians of Nablus to the Paris Peace Conference and allied states" says that this letter of protest signed by all of these people forms the credible popular opinion officially from the Nablus municipality. Zu'aytir, Watha'iq al-haraka, 12.

64 "Historical Sketch by Albert H. Lybyer of the Commission's Visit to Syria, 1 August 1919," report providing a narrative description of the King-Crane Commission's visit to different parts of the Levant," box 16/1, ALP/OCR: http://dcollections.oberlin.edu/cdm/compoundobject/collection/ kingcrane/id/2563 (accessed 25 Apr. 2014).

65 Zu'aytir, Watha'iq al-haraka, 7.

66 "An Analysis," box 7/1/6-7, WYP/BU.

67 "Strong National Feeling," ALP/OCR. Montgomery was also concerned with "Syrian national feeling," "Report by George Montgomery on Zionism, 1 July 1919," box 16/1, ALP/ OCR, at: http://dcollections.oberlin.edu/cdm/ref/collection/kingcrane/id/2300 (accessed 29 Dec. 2016). 
Arabs in the "direction of an Arab Moslem Confederation," which is where Yale believed the Arabs' ambitions pointed. ${ }^{68}$

It may be that the Arabs' demonstrations were too orderly for Yale. In a report about the Commission shortly after its conclusion he wrote: "The demands and wishes of the Syrians and the form of proclamations, declarations, petitions, etc. were cut and dried to the point of boredom." "69 Yale believed nationalism to be "a psychological force," and a matter to be judged according to the "intensity of emotional reaction." "I0 It depended on people accepting group ideas "as a political philosophy" that "stirs their emotions so profoundly that loyalty to this philosophy becomes the dominant loyalty over-riding ... all others." 71 Perhaps, then, the Arabs' quietness provided for him insufficient evidence of true nationalist spirit amongst the people. One wonders whether the colonized could ever have gotten the balance between nationalist enthusiasm and civilized behavior just right.

It is likely that no performance could have convinced Yale of the Arabs' sincere nationalism, given his orientalist views of "the Near Easterner," who he believed had "not fully emerged from the Middle Ages.",72 (These beliefs were shared by George Montgomery, another member of the King-Crane team). ${ }^{73}$ While Yale's views, which he recorded in a dissenting report from King and Crane, were not central in the final commission report, ${ }^{74}$ the point is that he could dismiss Arab political claims on the grounds of their emotions as he interpreted them.

Yale's interpretations of emotion served two purposes: they verified his expertise and, by disqualifying the Arab nationalist aspirations, bolstered the legitimacy of Western claims to rule. ${ }^{75}$ To him, the coherence of the Syrian petitions with which the Commission had been "incontinently inundated," their orderly submission, and the Arab demonstrations all lacked a spontaneity that might have indexed a more convincing, emotion-bound spirit. ${ }^{76}$ The Arabs were responding to Wilson's statements and the language of the League of Nations, which, as Jane Cowan has shown, disallowed "unruly

68 "Recommendations of the Future of Syria, Palestine and Lebanon, 26 July 1919," William Yale Collection, Middle East Centre, St. Antony's College, Oxford, box 1/4/6.

69 "Report in Detail of Interviews in London (Sept. 27, 1919 to Oct. 14, 1919)," box 5/4, WYP/ $\mathrm{BU}$.

70 "Reflections on Syrian Nationalism," box 5/3/319, WYP/BU; William Yale, The Near East: A Modern History (Ann Arbor: University of Michigan Press, 1968 [1958]), 192.

71 "Reflections on Syrian Nationalism," box 5/3/319, WYP/BU.

72 Yale, Near East, 4.

73 Report by George Montgomery on Syria, 1 Aug. 1919, box 16/2, ALP/OCR.

74 Yale's minority report is mentioned in Knee, "King-Crane Commission," 44; Patrick, "Reading the King-Crane," 25.

75 Compare Rutherford, "Sympathy," 9.

76 Ray Stannard Baker, Woodrow Wilson and the World Settlement: Written from His Unpublished and Personal Material, vol. II (Garden City: Doubleday, Page \& Co., 1923), 208. 
linguistic behavior" and censored violent, or passionate, expression. ${ }^{77}$ So while the Arabs were concentrating on demonstrating their reasonable, civilized nature and organized unity, they failed to put on a more demonstrable display of the proper emotion.

\section{POLITICS, EMOTION, AND AFFECT}

The variable uses of emotion, their deployment in political projects, and their range of effects on political actors have long been evident to anthropologists and others. Emotions are political and cultural, ${ }^{78}$ important to social unity, mobilization, and conflict management, ${ }^{79}$ and part of economic rationality. ${ }^{80}$ Although affect, rather than emotion, has been the trending focus in more recent anthropology, ${ }^{81}$ the definitional question remains. Exactly what distinguishes affect from emotion and sensibility from sentiment in lived experience and analytical approach is often unclear. There are also debates about the methodologies required to study emotion/affect. As Pinch points out, "The relationships among a historical period's talk about feeling, people's experience of feeling, and the historical meanings of feelings may not always be obvious." 82 There are two key issues that could productively be distinguished to move these discussions along. First, we must recognize that the question of

77 Cowan, "Who's Afraid?"

78 Ghassan Hage, "Hating Israel in the Field: On Ethnography and Political Emotions," Anthropological Theory, 9 (2009): 59-79; Catherine Lutz, "The Anthropology of Emotions," Annual Review of Anthropology 15 (1986): 405-36; Catherine Lutz and Lila Abu-Lughod, eds., Language and the Politics of Emotion (Cambridge: Cambridge University Press, 1990); Michelle Rosaldo, "Toward an Anthropology of Self and Feeling," in Richard A. Shweder and Robert A. Levine, eds., Culture Theory: Essays on Mind, Self and Emotion (Cambridge: Cambridge University Press, 1983).

79 Steve Caton, "Peaks of Yemen I Summon": Poetry as Cultural Practice in a North Yemeni Tribe (Berkeley: University of California Press, 1990); Deborah Gould, Moving Politics: Emotion and ACT UP's Fight against AIDS (Chicago: University of Chicago Press, 2009); Thomas Haskell, "Capitalism and the Origins of the Humanitarian Sensibility," parts 1-2, American Historical Review 90, 2-3 (1985): 339-61, 547-66; Yael Navaro-Yashin, The Make-Believe Space: Affective Geography in a Postwar Polity (Durham: Duke University Press, 2012).

80 Albert O. Hirschman, The Passions and the Interests: Political Arguments for Capitalism before Its Triumph (Princeton: Princeton University Press, 2013 [1977]); Martijn Konings, The Emotional Logic of Capitalism: What Progressives Have Missed (Stanford: Stanford University Press, 2015); Nancy Scheper-Hughes, Death without Weeping: The Violence of Everyday Life in Brazil (Berkeley: University of California Press, 1992).

81 Paul Manning, "Owning and Belonging: A Semiotic Investigation of the Affective Categories of a Bourgeois Society," Comparative Studies in Society and History 46 (2004): 300-25; William Mazzarella, "Affect: What Is It Good For?" in Saurab Dhube, ed., Enchantments of Modernity: Empire, Nation, Globalization (London: Routledge, 2008); William Mazzarella, “A Torn Performative Dispensation: The Affective Politics of British Second World War Propaganda in India and the Problem of Legitimation in an Age of Mass Publics," South Asian History and Culture 1, 1 (2010): 1-24; Kathleen Stewart, Ordinary Affects (Durham: Duke University Press, 2007); Kabir Tambar, "Iterations of Lament: Anachronism and Affect in a Shi'i Islamic Revival in Turkey," American Ethnologist 38, 3 (2011): 484-500.

${ }^{82}$ Adela Pinch, Strange Fits of Passion: Epistemologies of Emotion, Hume to Austen (Stanford: Stanford University Press, 1997), 101. 
how to trace the ways in which emotions are cultivated or affect is experienced is in part a methodological one that must be answered with relation to the specific kinds of material being analyzed. Second, we need to distinguish between affect and claims about affect (including claims to be able to judge it).

The problem of how and whether scholars as observers can make determinations about what affect is, and what affects (or emotions) are actually at play in any given interaction or social phenomenon, must necessarily return to the question of mediation, and demands sustained reflection on "the possibility of knowing through feeling." 83 How does affect become apparent to the analyst? Earlier studies of emotion considered this more explicitly by scrutinizing language, culture, or ideology as mediating frameworks, yet some more recent approaches to affect, especially those coming out of cultural studies and social geography, have tended to leave this issue under-examined, assuming an ability to recognize affect when scholars see, feel, or notice it.

Here is where our sensitivity to the imbrication of definition, method, and theory must be heightened. If affect is defined as "a non-conscious experience of intensity," how does the historian or ethnographer identify it? ${ }^{84}$ We live, learn, and communicate through symbols. If affect is that which is in excess of the symbolic, as some claim, ${ }^{85}$ then how can it be data or evidence for our scrutiny as outside observers? Emotion, on the other hand, the culturally mediated, feeling-part of the social that is evident in discourse about it, is more amenable to analysis. So too is any discourse or system of knowledge production that claims to offer evaluations of affect.

What some streams of "affect theory" claim to be trying to get hold of is an aspect of human experience and social life that seems to exist and have its effects in a realm that is not totally encompassed by discourse; affect is distinct from descriptions of it, distinct from, if not totally untouched by, culture. "Excess," "intensity," and "virtuality" are some of the words affect theorists typically use to try to convey this uniqueness. ${ }^{86}$ For some, affect is an excess beyond language or, perhaps, reason; a bridge that spreads across the binaries of individual and social, person and environment, mind and body. ${ }^{87}$ Affect is an "intensity" in that it is something felt and noticed beyond the ordinary humdrum of daily life.

\footnotetext{
83 Andrew Beatty, "Current Emotion Research in Anthropology: Reporting the Field," Emotion Review 5, 4 (2013): 414-22, 420.

${ }^{84}$ Ruth Leys, "The Turn to Affect: A Critique," Critical Inquiry 37, 3 (2011): 434-72; Nigel Thrift, "Intensities of Feeling: Towards a Spatial Politics of Affect," Geografiska Annaler 86 (2004): 57-78, 58.

85 Patricia Ticineto Clough, Introduction, in Patricia Ticineto Clough, ed. with Jean Halley, The Affective Turn: Theorizing the Social (Durham: Duke University Press, 2007), 1-33.

86 Ben Anderson, "Becoming and Being Hopeful: Towards a Theory of Affect," Environment and Planning D 24 (2006): 733-52, 738.

87 Athena Athanasiou, Pothiti Hantzaroula, and Kostas Yannakopoulos, "Towards a New Epistemology: The "Affective Turn," Historein 8 (2008): 5-16.
} 
To be sure, what colonial officials and commissioners were doing in their readings of natives' hearts and minds is something very different from what the affect theorists are up to, but there is a common thread. For the imperialists as much as the theorists, affect always means something that is at least partially hidden - hidden from reason or language, but somehow available to them to read, decode, and build conclusions on. This provides two forms of power: one is the freedom to interpret and assert, and the other is the claim to an extraordinary ability to read beneath the surface of things, which gives a privileged access to truth.

Because affect is veiled, unnamed, and inexplicit, for those who would find and name it the scope for interpretation and assertion is wide indeed. The vagueness of the immanent-that-is-affect is precisely what allowed Yale to be bored by what, in Lybyer's view, was the Arabs' enthusiasm and earnestness. ${ }^{88}$ Perhaps each saw what he wanted to see.

Yale was particularly concerned to present himself as the hardnosed colonial "expert," the one who could read into the hearts of the local people and discover the superficiality of their political commitment to the nation. He distinguished himself from the political naïfs like Lybyer who he was forced to work with, and remained unswayed by idealistic liberalism. ${ }^{89}$ His contact with "the peasants of the Near East" is what allowed him to understand the true nature of their "passionate attachments" to their villages and families, and to see that these affections did not extend across the unified nation that the Syrian elite were asking for. ${ }^{90}$ The expert is the one who can extract the truth of the natives' motivations and intentions lurking beneath their stated commitments, aims, and goals. ${ }^{91}$ Attesting to his own "real love for Syria," Yale defended his conclusions about the absent Arab nationalism by declaring his "sincere hope to see Syria eventually a united country with a genuine national spirit." ${ }^{92}$ He contrasted his own sincerity, love, and hope with the destructive religious intentions and motivations of those demanding independence. His was the power to distinguish the real from the professed, the

\footnotetext{
${ }^{88}$ Affect is the realm in which political actors can engage in a "politics of immediation," through which privileged access to reality or truth can be asserted. For related discussions, see Lori Allen, "Martyr Bodies in the Media: Human Rights, Aesthetics, and the Politics of Immediation in the Palestinian Intifada," American Ethnologist 36, 1 (2009): 162-63; Mazzarella, "Torn Performative," 2010.

${ }^{89}$ Box 4/2, WYP/BU. "Observations on the King-Crane Commission."

90 William Yale Collection, University of New Hampshire, box 2, MC21/11/3; also Howard, King-Crane Commission, 70-71.

${ }^{91}$ For an exegesis of how reading and measuring emotion has figured in the history of colonial counterinsurgency, see Laleh Khalili, "The Uses of Happiness in Counterinsurgencies," Social Text 118, 32, 1 (2014): 23-43.

92 "Strong National Feeling," ALP/OCR.
} 
capacity to see through the murky realm of alleged emotion to the true feelings and dangerous intentions within. ${ }^{93}$

My argument, then, is not in line with the call of the "affective turn" to attend to the "autonomic processes" and "visceral' forces" below the threshold of consciousness and meaning. The noble intention of this scholarship to make up for a history of social theory in which, supposedly, "philosophers and critics have largely neglected the important role our corporeal affective dispositions play in thinking, reasoning, and reflection" is valid enough. ${ }^{94}$ But my concern lies elsewhere, with the fact that affect, and specifically the claim to be able to interpret it, has been a critical instrument in consolidating regimes of power and denying rights to the dispossessed. Commissions to Palestine prompt questions about how the false claim of colonial and imperial powers to govern through reason and value rationality above all has been understood by the colonized. Uncovering how and why political contenders - and not only we social analysts - recognize and misrecognize the place of sensibilities and sentiments within political reasoning provides one key to understanding the hegemony of international management of various conflicts, and the persistent failure of Palestinians to achieve statehood. ${ }^{95}$

THE ANGLO-AMERICAN COMMITTEE OF ENQUIRY, 1945-1946

For decades, Palestinians have been trying to argue that a political solution is required to remedy their situation. But since World War II they have been up against the particularly poignant humanitarian and emotional claims of the Zionist movement, which sought to make Palestine a homeland for the Jews. In my next case, the Anglo-American Committee of Enquiry, the Palestinians are once again subject to a forensic reading of their emotions, and once again the affective regime shifts with the introduction of new criteria and the new mediating factor of the Holocaust. The colonial demand for a balance between emotion and political reason becomes impossible to meet, now held out of reach by the traumatic historical experience of the Jews.

Earl G. Harrison, who Truman had sent in 1945 to study the condition of displaced persons in Europe, wrote a report that "stirred Truman's sympathy for the Jews and alerted him to an issue that would arouse the political as well as the humanitarian emotions of the American public." 96 This led to the formation

93 For parallel dynamics in recent Palestinian politics, see Lori Allen, "Sincerity, Hypocrisy, and Conspiracy Theory in the Occupied Palestinian Territory," International Journal of Middle Eastern Studies 48, 4: 701-20.

94 Leys, "Turn to Affect," 436, 437.

95 On misreading the emotional terrain of diplomatic interactions, see Winifred Tate, "Proxy Citizenship and Transnational Advocacy: Colombian Activists from Putumayo to Washington, DC," American Ethnologist 40, 1 (2013): 55-70; "Human Rights Law and Military Aid Delivery," PoLAR: Political and Legal Anthropology Review 34, 2 (2011): 337-54.

96 Wm. Roger Louis, The British Empire in the Middle East: 1945-1951: Arab Nationalism, the United States, and Postwar Imperialism (Oxford: Clarendon Press, 1984), 388. 
of the Anglo-American Committee, which was to "examine the question of European Jewry and to ... review the Palestine Problem in light of that examination." 97 Truman, who continually expressed compassion for refugees to his Jewish constituency, had urged the American chair of the Anglo-American Committee to produce a report that would recommend "an affirmative program to relieve untold suffering and misery." 98 The Committee was formed, then, through what we might call, following Peter Redfield and Erica Bornstein, a humanitarian structure of feeling, "a cluster of moral principles, a basis for ethical claims and political strategies, and a call for action." 99

For their part, the Palestinians persisted with the political logic of their case. In their presentation to the Anglo-American Committee, they explained their opposition to the Zionists' plan to turn Palestine into a Jewish state. Their own position, they said, was based on democratic principles: "the right of a majority to decide its political destiny." 100 Among the Palestinians who prepared a presentation to the Committee, there was a clear concern with presenting hard evidence and keeping emotional expressions in check. In the memoirs of Yusif Sayigh, a Palestinian economist who contributed research for the Palestinian written submission to this Commission, he discusses how his input was shaped. He had been asked to prepare a report assessing the extent and nature of Arab land holdings. When Sayigh wrote his contribution he held only a BA degree, though he went on to earn a doctorate in political economics from Johns Hopkins and became a full professor at the American University of Beirut. But at the time, he noted in his memoirs, his English "wasn't all that good," so he had a friend edit his paper. ${ }^{101}$ Sayigh's British friend "took away all the things that showed anger or emotionalism." These strong feelings, which he said appeared in his writing, were prompted by his discoveries about the "awful things, about the injustice, the eviction of hundreds of families from the Esdraelon plain [also known as the Jezreel or Zir'een Valley]. Twenty-three villages were evicted." ${ }^{102}$ Sayigh recounts that his friend told him, "Calm down, you're writing for Britishers and for Americans. If they see this you'll lose the strength of your point." ${ }^{, 103}$ He persuaded

\footnotetext{
97 Evan M. Wilson, Decision on Palestine: How the U.S. Came to Recognize Israel (Stanford: Hoover Institution Press, 1979), 73.

98 Louis, British Empire, 420.

99 Peter Redfield and Erica Bornstein, "An Introduction to the Anthropology of Humanitarianism," in Erica Bornstein and Peter Redfield, eds., Forces of Compassion: Humanitarianism between Ethics and Politics (Santa Fe: School for Advanced Research Press, 2010), 17.

100 Arab Office, The Future of Palestine (London: The Arab Office, 1947), 70.

101 Rosemary Sayigh, ed., Yusif Sayigh, Arab Economist, Palestinian Patriot: A Fractured Life Story (Cairo: American University in Cairo Press, 2015), 188.

102 Ibid. Also see, Mark Tessler, A History of the Israeli-Palestinian Conflict, $2 \mathrm{~d}$ ed. (Bloomington: Indiana University Press, 2009), 177.

103 Sayigh, Yusif Sayigh, 188.
} 
Sayigh "to tone things down here and there." 104 But the crafting and drafting of the appropriate tone could do little to budge the order as it existed, with the suffering Jews the paramount victims overshadowing all other considerations.

Despite the efforts of Sayigh and his colleagues to avoid any expression of anger that might suggest that their facts were not credible or were biased, members on the Anglo-American Committee of Inquiry were mostly unimpressed by the Arabs' case. Evan Wilson, a secretary to the American members of the Committee and Palestine desk officer in the U.S. Department of State, wrote that the Arabs' testimony was badly organized and bespoke their lack of leadership. ${ }^{105}$ Echoing Yale's complaint about the boring uniformity of the petitions submitted to the King-Crane Commission, Wilson dismissed the Arab presentations to the Anglo-American Committee as being "mostly a repetition of the standard Arab argument that Palestine was Arab and the Jews were interlopers."106 Although the Arabs had long based their arguments on the principle of self-determination proposed by Woodrow Wilson at the end of World War I, the Americans and British did not interpret the Arab argument as a principled and consistent political stance, but rather as "rigid and unimaginative." $" 107$

The investigators did have a begrudging appreciation for one speaker: Albert Hourani, an Oxford-educated scholar whose family was from Lebanon. He was working for the Arab Office, a small diplomatic and public relations team for the Palestinians organized to lobby the British and American governments and Western public opinion. The Arab Office produced the Palestinians' main presentation for the British and American investigators. According to the eminent Palestinian historian Walid Khalidi, who had once been a young member of staff at the Arab Office, Hourani and his Oxford training set the tone of the Arab Office's work. Khalidi explained to me their approach: "The idea was to not be polemical," he said, "but to be factual. To be documented. To have supporting evidence for whatever you said. To be tough without being vulgar or extravagant." 108 They were well aware that how different emotions were expressed "provided both cultural and legal 'proof' of who one was, where one ranked in the colonial order of things," as Ann Stoler puts it. ${ }^{109}$ Khalidi said they also tried to put themselves "in the shoes of the other side." As it turned out, their empathetic efforts were off-target.

The commissioners conceded that Hourani "did a brilliant job of presenting the Arab side, comparable to Weizmann's for the Jewish." ${ }^{110}$ But the force

\footnotetext{
104 Ibid.

105 Wilson, Decision on Palestine, 84-85.

106 Ibid., 76.

107 Ibid.

108 Author's interview with Walid Khalidi, 2013.

109 Stoler, Along the Archival Grain, 40.

110 Wilson, Decision on Palestine, 76.
} 
of his testimony was weakened, his credibility tarnished, and his morality called into question because he fell short on expressing a crucial emotion: sympathy. When one of the Commissioners questioned him on the Arabs' demand that Jewish immigration to Palestine stop, the commission's secretary reported, "He would not agree to the admission of a single additional Jew to Palestinenot even the aged and infirm among the displaced persons." 111 Indeed, the Arab Office stance was clear: the doors of Europe and America should be opened to the victims of the European war, not the politically fragile Holy Land. ${ }^{112}$

What struck the Committee was "this completely intransigent stand," rather than Hourani's argument. Hourani had tried to explain that sympathy for the displaced Jews of Europe could not be addressed as if they existed in a political vacuum: "It is unhappily impossible," he said, "to consider the question of immigration simply on humanitarian grounds.... The question of immigration into Palestine must be seen in its general political framework." ${ }^{114}$ This point was subsequently echoed in the response to the report submitted by The Institute of Arab American Affairs. Signed by Faris S. Malouf and John Hazam, the memorandum asserted, "No solution of the humanitarian aspect of the 'displaced' and 'persecuted' Jews can be discussed, let alone solved, without taking into consideration the wider political aspects of Palestine and the Arab world." They encouraged compassion for victims of the Nazis, but not if it violated "the inalienable rights of the Arabs." 115 Hourani and the Arab Office presented these views at a time when some Palestinians (although a decreasing number) believed coexistence with the Jews already in Palestine was still possible, ${ }^{116}$ but thought mass immigration to Palestine would spell the destruction of that shared existence.

For a variety of reasons related to U.S. politics, including Truman's terror "of incurring the ill-will of the very powerful Zionist lobby and of its loyal blocs of voters in key states," the president was focused on the displaced Jews as the singular, prioritized problem, which was to be solved through realization of Zionist goals. ${ }^{117}$ On the heels of the Anglo-American Committee report, Truman called for the admission of a hundred thousand Jews to

111 Ibid.

112 British Foreign Secretary Ernest Bevin also agreed with this point. Louis, British Empire, 4.

113 Wilson, Decision on Palestine, 80.

114 Walid Khalidi, ed., "The Case against a Jewish State in Palestine: Albert Hourani's Statement to the Anglo-American Committee of Enquiry of 1946," Journal of Palestine Studies 35, 1 (2005): $89-90,85$.

115 "Memorandum of The Institute of Arab American Affairs on the Recommendations of the Anglo-American Committee of Inquiry" (New York: Institute of Arab American Affairs, 1946), 8.

116 Zachary Lockman, Comrades and Enemies: Arab and Jewish Workers in Palestine, 19061948 (Berkeley: University of California Press, 1966), 274, 322-23.

117 Louis, British Empire, 387; also see William A. Eddy, "F.D.R. Meets Ibn Saud: The Conference and Its Anticlimax, 1945," in Walid Khalidi, ed., From Haven to Conquest (Beirut: Institute for Palestine Studies, Beirut, 1971), 512. 
Palestine. Soon thereafter the state of Israel was established, and some seven hundred and fifty thousand Palestinian Arab refugees were dispossessed of their homeland.

The Arab Office that Albert Hourani worked with was staffed by selfdescribed "decent, liberal, approachable people," Albert's brother and director of the Washington branch of the Arab Office (between 1946-1948), Cecil Hourani, told me in an interview. But Hourani and his team had violated the "conventions of sympathy," a feature of political discourse about Jews in World War II that was entrenched by that time. ${ }^{118}$ Although Palestinians argued that sympathy for the Jews should not come at the expense of their national rights, the former won out. Ultimately, the affective conventions of the day recognized only one set of sentiments as justifying territorial rights, in the process subordinating Arab political claims to Jewish ones.

Similar to what Ann Stoler has discovered in the Dutch colonial archives, rulers in Palestine have also been preoccupied with appraisals of affect. ${ }^{119}$ The unequal value that these statesmen have given to emotion, ideology, and reason in assessments of Palestinians has been changeable, if not capricious. While Arabs faced skepticism about the sincerity of their nationalist sentiment during the King-Crane Commission, they were discounted for their lack of sympathy during the Anglo-American Commission. The way these commissions worked to unearth thoughts and feelings reveals that the judgment of evidence is always, and has always been, as much a process of "affective discernment" as an evaluation of supposedly "objective" fact. ${ }^{120}$

\section{THE MITCHELL COMMISSION, 2001}

The Mitchell Commission, my last case, provides a final telling example of the changing role of affect in the international community's ways of understanding, and governing, the Palestinian-Israeli conflict. It raises questions about how, and whether, Palestinians can meet the ever-mutating and unspoken criteria of political judgment and the shifting place of emotions within it. These historical shifts show how emotion and reasoned, factual discourse are accepted as evidence in ambivalent, if not contradictory ways.

The Mitchell Commission, officially the Sharm El-Sheikh Fact-Finding Committee, released its report on 30 April 2001, about six months after then U.S. President Clinton called for it at the conclusion of the Middle East Peace Summit at Sharm el-Sheikh. The Commission's purpose was said to be to "end the violence, to prevent its recurrence, and to find a path back to

\footnotetext{
118 Deborah Nelson, "Suffering and Thinking: The Scandal of Tone in Eichmann in Jerusalem," in Lauren Berlant, ed., Compassion: The Culture and Politics of an Emotion (London: Routledge, 2004), 220.

119 Stoler, "Affective States."

120 Later examples are found in Lori Allen, The Rise and Fall of Human Rights: Cynicism and Politics in Occupied Palestine (Stanford: Stanford University Press, 2013).
} 
the peace process." ${ }^{\prime 21}$ Dispatched about a month after the second Palestinian intifada began, it was not to be "a tribunal but [a committee] to find out what happened and prevent recurrence."122

The investigation involved the gathering of, on one hand, technical and legal evidence, and on the other, hearing personal stories of violence and victimhood. Throughout their political history, Palestinians' efforts to inform and convince through the accumulation of material evidence fell short of commissioners' affective expectations until the Mitchell Commission, when Palestinian responsiveness to that demand was heightened. This more recent commission exhibits a widened focus on the suffering and testimony of individual victims, and also shows how the Palestinian understanding of the commission differed in some marked ways from that of the investigators.

One key person on the Palestinian legal team that was responsible for producing the written submissions and guiding the Committee in the West Bank understood that the approach to presenting their case was legal. Another team member likened it to "a civil law case." He said they organized the ballistics, the maps, and the numbers of settlements as if they were "presenting the evidence to the judge." As another understood the law, it was "very much seen as a genuine part of the Palestinian narrative. So by using the law, we were using tools and terms that were at least familiar to the Palestinian leadership. It's in keeping with the traditional way Palestinians have done things."

In interviews with me, American staff of the Mitchell Commission talked about the evidence they received as existing on a spectrum from "the rational to the emotional." Ultimately for them, the form of the presentation did as much work - and left more of an impression - than the substance of what Palestinians said and argued. In preparing their reports for the Commission, the Palestinian team "spent tons of time trying to actually find out the details; who was killed, the names of the people who were killed. Because we did not want to be attacked on bad data," as one of the Palestinian lawyers recalled. But the Commission received their painstaking legal submissions in a pro-forma way. $^{123}$ Even though what the Palestinians thought they were doing was making sure that "all the evidence [was] on the table," presenting the commission "with as much data, facts, and first hand evidence as possible," the

121 The report is available at: http://2001-2009.state.gov/p/nea/rls/rpt/3060.htm (accessed 29 Dec. 2016).

${ }_{122}$ The Mitchell Commission's final report highlighted the importance of rebuilding confidence between Palestinians and Israelis and resuming negotiations, for Palestinians to end terror, and for Israelis to freeze settlements.

123 The Palestinians' submissions were prepared by the staff of the Negotiation Support Unit, a group made up mostly of relatively young lawyers, most of whom were Palestinian or Palestinian-American, or of Arab background or heritage. One of them called it "the one centerpiece of Palestinian diplomacy." Files in author's possession (the three written submissions are no longer available online). 
Commission staff did not pour through the evidence. As one of the investigative team told me, he "took [written] submissions with a grain of salt" since he "knew what could be expected" out of both parties. Instead of focusing on this "cold dry paper," one of the American staff said, "we needed to understand ... to walk in their shoes."

The Palestinians organizing their field visits sought to allow the investigators to do just that. Their new focus on the suffering of Palestinian victims marked a change from earlier inquiries. The Palestinian staff sought to "bring home" to the investigators experiences of occupation and violence, to give them a "physical sense" of it, as one told me. "When [the Committee] came on the ground [in Palestine], we made sure that they went to the hospital that was bombed and met the families of the people that were bombed or imprisoned.... You have the [written] submission, which is solid law, then you have the facts, then tear jerkers." But none of the Palestinian staff considered these personal stories to be the main focus of their presentation to the Committee.

Although foregrounding this emotional dimension was not key to the strategy of the Palestinian lawyers, it ultimately was the testimony and emotional impact of non-professional, non-politicians that the Mitchell staff perceived to be most authentic, and that convinced them the most. What the Americans recalled twelve years later when they spoke to me were these shared experiences: seeing the large bullet hole from Israeli fire in a little Palestinian girl's bedroom, or receiving a bag full of shells from distressed parents. They remembered moments of emotional recognition and understanding they shared with both Israelis and Palestinians.

These were moments of what Lauren Berlant calls "sentimentality ... when emotions communicate authenticity that enables identification and solidarity among strangers." ${ }^{24}$ As an American staffer said, "It didn't seem like you were talking to a professional communicator who has an agenda. These are people who had families and shops and this is what they had experienced." Relying on their "affective discernment," 125 the commission staff put their faith in the apolitical, personal stories - not Hanan Ashrawi's reasoned discourse about the history of the occupation, not the speech about democracy by a populist street leader, and not the requirements of international law presented in the Palestinians' legalistic, written submissions. In the end, what persuaded the Americans was the evidence gathered in another register: their empathy-inducing interactions with "regular" people.

124 Sina Najafi, David Serlin, and Lauren Berlant, "The Broken Circuit: An Interview with Lauren Berlant," Cabinet Magazine 31 (Fall 2008): http:/www.cabinetmagazine.org/issues/31/ najafi_serlin.php (accessed 8 Dec. 2016).

125 Ibid. 
The Commission staff told me that they were from the beginning concerned with keeping the investigation as "objective" as possible. And the Palestinian staff who interacted with them believed them to be "genuine." "They took their job seriously," as one said. Another said he was surprised at how "open minded" and "objective" they turned out to be. This attempt at a balanced approach was evident in the Mitchell Commission's report. It makes multiple references to "both sides," and to the different "perspectives" of the PLO and the Government of Israel. The report was also highly attuned to the emotional scene of the second intifada. It acknowledged the "humiliation and frustration" that the Palestinians experience under occupation; it sought ways to reduce the hostility and mistrust between the parties; it worried about hatred, and about the Israelis' fear; it recognized anger on "both sides." Whereas the Palestinian lawyers who organized the presentations to the Mitchell investigators focused on using law as a way to produce "an easily digestible narrative from the Palestinian side," the fact-finders heard the suffering and grief of Palestinians and Israelis, and were, in the words of the report, "touched by their stories."126 As political analyst Mouin Rabbani stated in his critique of the Mitchell report, it gives the impression that "the Committee was investigating a confrontation between equal forces, each equally responsible for the "violence." 127 And in the end, the turn to emotion as the authenticating ground of proof resulted in a false equivalence between Palestinian and Jewish experiences, even if, in this commission, there was more sympathy for the Palestinians' feelings and frustrations.

\section{CONCLUSION}

Each of these three investigative commissions into the Israeli-Palestinian conflict, like many others over the past century, have offered languages of political legitimacy and legitimization for Palestinians to appropriate, maneuver within, and present arguments through. ${ }^{128}$ All were invitations to prove political worthiness. Palestinians demonstrated in the very form of their interactions with successive commissions "appropriate" political subjectivities: nationally coherent, democratically principled, law abiding, rights demanding, and suffering.

Commissions in general often hold up the promise of reasonableness in policy-making. They invite concerned parties into public discussion to prove themselves reasonable political subjects, and promise to rationally consider their interests and make judgments based on evidence. Commissions offer this hope, and yet their reports are put in a drawer and forgotten. They often

\footnotetext{
126 Although the official PLO response to the report (available at http://www.al-babz.com/arab/ docs $/ \mathrm{pal} / \mathrm{mitchell3}$.htm) noted that it did not fully address all of their concerns, they confirmed its "balanced assessment of the facts" and supported the implementation of the Committee's recommendations.

127 Mouin Rabbani, “The Mitchell Report: Oslo's Last Gasp?” Middle East Report Online, 1 June 2001: http://www.merip.org/mero/mero060101 (accessed 29 Dec. 2016).

128 See Wheatley, "Mandatory Interpretation," 221.
} 
have no discernable effect on political outcomes, since the governments that send them have pre-existing political goals that shape the investigations and how their recommendations are taken up or, more often, ignored. My argument here is that the effects of these commissions have worked in a different register. They have misled Palestinians into believing that decisions would be based on the evidence Palestinians presented, and that their reasoned arguments were being considered according to rational criteria.

It is crucial to recognize that commissions are themselves a method of persuading Palestinians and others that dialogue and civility are the means to resolve the conflict, and that international management of the conflict is happening on a firm basis of objective fact. In so doing, they have shaped a false sense of what "the emotional economy" of empire is. ${ }^{129}$ Despite the investigative experts' stated commitment to reason as a modality of both claims-making and evaluation, emotion is never edited out, and in fact is often central. Claims about affect, and experts' claims to be able to judge affect - to know interior states, feelings, and true intentions - are themselves politically powerful. They justify some people in their roles as expert and validate their policy recommendations. That the enactment and analysis of emotion has been such a significant means of gathering proof and evaluating Palestinian claims illuminates the wider emotional economy of imperialism and how it encourages Palestinians into particular performances. ${ }^{130}$

The turn toward emotion as the evidentiary ground of testimony has been increasingly explicit over the course of the three commissions as the international context and international governance structures changed over this period. This trajectory began in the Wilsonian era of the League of Nations when Westerners were concerned with the protection of minorities, continued through the United Nations and the instantiation of human rights as a hegemonic legal and moral political language, and then to American dominance internationally and as a "peace broker" for the conflict. Throughout, Palestinians have persistently called on democratic principles, demonstrated national coherence, and stressed the injustice of foreign usurpation of their homeland,

129 Stoler, Along the Archival Grain, 68.

130 In both the Palestinian case and that of the Australian aboriginals as analyzed by Elizabeth Povinelli, it is evident that the less powerful try to make themselves legible to those in control of resources. Povinelli argues that the colonial state has compelled subaltern subjects to "identify with the impossible object of an authentic self-identity," inspiring in them "impossible desires." Somewhat similarly, the "cunning" of commissions reinforces a false message of what are the political criteria according to which the colonized are being judged. But commissions do not skew Palestinians' subjectivity or their political aims. Palestinians have been demanding independence consistently and for a long time; upholding democratic principles is not simply a disciplining imposition from above. There are similar effects, however, in that commissions may enable the continuity of colonial settler practices by reducing the efficacy of Palestinian resistance to them. Elizabeth A. Povinelli, "The Cunning of Recognition: A Reply to John Frow and Meaghan Morris," Critical Inquiry 25, 3 (1999): 631-37, 633. 
always using logical and reasoned arguments. But reading affect has always been central to how the commissions have carried out their investigations, and always present in how the conflict has been managed and evaluated.

Those deemed appropriate to speak for the Palestinians have also varied since the Mandate period, when religious leaders and "notable" families were prominent. Since then, more space has opened for the voices of the intelligentsia, academics, technocrats, and legal practitioners, with increasing attention given to "ordinary" people and NGO workers, as the human rights regime has come to frame Palestinian political appeals. ${ }^{131}$ These changes reflect international political dynamics as a global moral order (or at least a pretense to one) has come to be embodied in the human rights and humanitarian system privileging not just international human rights and humanitarian law, but also the testimony of the violated, especially since the 1970s. ${ }^{132}$ While the specific demands and "key words" of these political appeals have changed, reasoned and evidence-based presentations have remained a consistent form in which Palestinians have put forth their demands.

Although commissioners have claimed to valorize reasoned argument as the preferred political method, and to operate with objectivity and reasoned fairness, they have never privileged reasoned argument alone. Contrary to the dominant claims of Western political discourse, which are sometimes taken at face value in the counter-histories of social theory found in the "affective turn," reasoned argument has never been the only currency of the normative democratic public sphere. ${ }^{133}$ What the Palestinian experience points to for social theory, then, is the need to inquire more into the social, governmental, and political institutions that have simultaneously made affective states indices of political legitimacy and obscured their significance. We need to understand not just affect as a part of colonial subjugation, or politics generally, but how and why the powerful role of determining and defining correct affect has been concealed.

131 On sociological changes in the Palestinian leadership, see Jamil Hilal, "West Bank and Gaza Strip Social Formation under Jordanian and Egyptian Rule (1948-1967)," Review of Middle East Studies 5 (1992): 33-74, 52; and The Formation of the Palestinian Elite: From the Palestinian National Movement to the Rise of the Palestinian Authority (Ramallah: Muwatin, the Palestinian Institute for the Study of Democracy, 2002).

132 Didier Fassin, "The Humanitarian Politics of Testimony: Subjectification through Trauma in the Israeli-Palestinian Conflict," Cultural Anthropology 23, 3 (2008), 531-58; Stephen Hopgood, The Endtimes of Human Rights (Ithaca: Cornell University Press, 2013); Samuel Moyn, The Last Utopia: Human Rights in History (Cambridge: Belknap Press of Harvard University Press, 2010).

133 According to some scholars, in the dominant claims of Western political discourse reasoned argument is at the center of the normative democratic public sphere. See Nancy Fraser, "Rethinking the Public Sphere: A Contribution to the Critique of Actually Existing Democracy," Social Text 25, 26 (1990): 56-80; Jurgen Habermas, The Structural Transformation of the Public Sphere: An Inquiry into a Category of Bourgeois Society, Thomas Burger with Frederick Lawrence, trans. (Cambridge: M.I.T. Press, 1989). 
Abstract: The conflict in Palestine has been the subject of numerous international investigative commissions over the past century. These have been dispatched by governments to determine the causes of violent conflicts and how to resolve them. Commissions both produce and reflect political epistemologies, the social processes and categories by which proof and evidence are produced and mobilized in political claim-making. Using archival and ethnographic sources, my analysis focuses on three investigative commissions: the King-Crane (1919), AngloAmerican (1946), and Mitchell (2001) commissions. They reveal how "reading affect" has been a diagnostic of political worthiness. Through these investigations, Western colonial agents and "the international community" have given Palestinians false hope that discourse and reason were the appropriate and effective mode of politics. Rather than simply reason, however, what each required was maintenance of an impossible balance between the rational and the emotional. This essay explores the ways that affect as a diagnostic of political worthiness has worked as a technology of rule in imperial orders, and has served as an unspoken legitimating mechanism of domination.

Key words: Palestine, Israel, United Nations, rights, affect, nationalism, League of Nations, colonialism, King-Crane Commission, Anglo-American Committee of Inquiry 